\title{
Minha vida como estudante no mundo dos brancos
}

DoI

http://dx.doi.org/10.11606/ 2179-0892.ra.2017.132066

\section{Nelly Duarte}

- Museu Nacional/UFRJ | Rio de Janeiro, RJ, Brasil

$\boldsymbol{\nabla}$ nellydollis@gmail.com

\section{RESUMO}

Este texto foi escrito em função de um convite para conversar sobre a política de ação afirmativa para ingresso no Programa de Pós-Graduação em Antropologia Social do Museu Nacional da Universidade Federal do Rio de Janeiro. Como estudante indígena marubo, conto nestas páginas como aconteceu meu ingresso na sociedade não indígena. Esta reflexão passa necessariamente por uma apresentação de minha etnia e mais especificamente de minha família, o difícil caminho que me levou a estudar até chegar à universidade e, por fim, as maneiras que encontrei para vencer os obstáculos mais variados. Concluo com uma avaliação sobre a importância das ações afirmativas na pós-graduação e o papel das lideranças indígenas nesse processo.
PALAVRAS-CHAVE

Ações afirmativas, Racismo, Pósgraduação, Povos indígenas, Antropologia social. 
Vou contar como ingressei na sociedade não indígena. Sou indígena da etnia Marubo - apresentação que não faz muito sentido entre quem é dessa etnia, já que o mais adequado nesse caso seria indicar a qual clã pertenço-, e vim da Terra Indígena do Vale do Javari, localizada no sudoeste do estado do Amazonas, na fronteira do Brasil com o Peru. Sou oriunda de uma aldeia erguida em 1977 pela Fundação Nacional do Índio (Funai) na calha do Rio Curuçá, denominada como Posto Curuçá ou PI (Posto Indígena) Curuçá, já que cada posto instalado pela Funai era identificado pelo nome do rio mais próximo para facilitar chamadas de rádio feitas pelos Chefes de Postos responsáveis. Em 1998, essa aldeia foi abandonada pela minha família por conta da escassez da caça, da perda da fertilidade da terra para plantio e da morte da liderança Maria Nascimento, uma figura importante dessa aldeia. A nova aldeia para onde foram os antigos habitantes passou a ser chamada de São Sebastião.

Surgi dos meus pais chamados Ranẽ Tupanë (rane-nawa) e Tamã Shëta (tama-oavo), e gosto de me apresentar pelo primeiro nome que recebi quando criança, Varĩ Mëma, porque ele tem a ver com a forma como eu vim ao mundo. Nessa minha apresentação, também não posso deixar de mencionar a pessoa mais importante da minha vida, já que tenho orgulho de dizer que sou neta de Niwa Wani/Itxãpapa, denominado pelos não indígenas como João Tuxaua. Meu avô foi conhecido entre seu povo como Arisma (que significa "guiado por vários espíritos"), e teve papel importante no tratamento de fertilização das mulheres que já não podiam ter filhos na sua sociedade: em alguns momentos ele teve que agir como pai de todos, porque a responsabilidade de estar casado com sete mulheres de clãs distintos o obrigou a ter um discurso de harmonia geral. A população marubo havia se reduzido bastante com ataques de vírus da gripe e com a desarmonia entre a população, fatos ocorridos em 1948, segundo o cálculo feito pela minha família de acordo com o contato que tiveram com povos nawas (não indígenas, brancos). Meu avô foi muito importante no meu desenvolvimento em dois mundos ao mesmo tempo, ele me acompanhava espiritualmente e onde quer que eu estivesse eu acreditava tanto nele que tudo que ele falava para mim se tornava real, e continuo até hoje vivendo a forma como ele descreveu que seria minha vida.

Estar atuando na academia hoje foi resultado do contato com os nawas, algo que fez meu pai pensar na possibilidade de uma das filhas aprender o conhecimento dos brancos, de aprender a ler e a escrever, para mais tarde ensinar a outros parentes, sem pensar muito na ruptura que isso iria ocasionar. $O$ sonho do meu pai não envolvia muita coisa: bastava aprender a falar, ler e escrever em português que em sua visão eu já estaria capacitada a atuar em muitas áreas, em especial lecionar e administrar medicamentos. Em função dessa ideia, que ele tinha desde que éramos crianças, meu pai tentou nos ensinar um pouco 
do que ele aprendeu com um funcionário da Funai que alfabetizou alguns indígenas de uma aldeia próxima, em 1974. Segundo contam, essa ação não durou muito porque ele começou a namorar duas irmãs no intuito de praticar a tradição dos Marubo, o que fez com que estes parassem de frequentar suas aulas, desaprovando sua atitude.

Como meu pai viu que não teria como dar continuidade às lições, já que não dispunha de material didático, pôs fim à sua ideia de dar aulas na aldeia. Naquela época, os índios não tinham muita noção do que era estudar e muitos Marubo acharam que meu pai tinha ideias excêntricas. Conforme ele me contou, esse seu modo de pensar surgiu por ter convivido bastante com comerciantes fluviais (os chamados "regatões") quando era jovem. O pai do meu pai morreu do vírus da gripe quando ele era ainda criança, deixando-o desamparado. A partir de então, ele preferiu estar com os nawas, e só não continuou esta vida de querer viver com os nawas porque o único tio dele por parte da mãe o impediu. Com toda essa história, ele pensou em realizar o sonho de aprender a falar bem, a ler e a escrever, por meio das filhas, e então procurou o regatão que batizou minha irmã mais velha, para que pudesse acolhê-la em sua casa, já que era sua afilhada. Meu pai se baseava no entendimento de que o nawa que dá o nome a uma criança tem uma responsabilidade com sua educação, desde que tenha as condições financeiras para tanto, segundo o que ouvia falar dos nawas naquela época. Este senhor aceitou de imediato o pedido do meu pai, mas, por estar namorando, minha irmã não quis aprender a ler e a escrever. Meu pai não insistiu muito e retornou com ela para a aldeia (o ano era 1986), mas em compensação, ao chegar, lá ele jogou toda a culpa em minha mãe pela atitude irresponsável da minha irmã em não ter aceitado estudar. Acabou que todo o ódio e a vergonha da minha mãe sobraram para mim. Ela acabou pedindo ajuda para um irmão que havia conseguido vaga para os dois filhos estudarem no convento na cidade de Cruzeiro do Sul, no Acre.

Minha estadia por lá não deu certo: em pouco tempo, meus pais souberam, por parte das mulheres do meu tio, dos maus tratos que sofri e mandaram me buscar. Ao retornar para junto dos meus pais, conhecemos o Bispo do Alto Solimões, Dom Alcimar Caldas Magalhães, da Igreja Católica, que estava visitando as aldeias em seu trabalho na Pastoral Indigenista. Na conversa que ele teve com meu pai, surgiu a possibilidade de eu estudar na cidade, e não muito depois de sua visita à aldeia eu fui à cidade de Benjamim Constant (AM), onde havia uma das casas do Bispo. Meu tio paterno, Américo, meu pai e eu descemos de canoa grande e levamos três dias de remo para chegar à cidade. Eu mal conseguia imaginar como seria minha vida daí para a frente. Crescia em mim uma sensação de abandono, mas não podia demonstrá-la, porque não queria ser mais uma filha a trazer decepção para meus pais, e transformei esse sentimento 
em força para viver em meio a distintas pessoas numa realidade totalmente diferente da minha, para mostrar que eu não precisava ter nascido homem para dar orgulho à minha família.

Fiquei na casa do Bispo de Benjamin Constant por volta de dois anos. Como se tratava de uma casa de trânsito do Bispo, eu não podia permanecer ali por muito tempo, e ele me levou para outra casa em Tabatinga, município vizinho onde ele morava há mais tempo. Ali tampouco se podia morar por muito tempo por ser casa de trânsito dos padres que faziam visita ao Alto Solimões com trabalhos sociais. Voltei a Benjamin Constant para ficar na casa da mãe de um padre chamado Josiney, porém, como o Bispo não podia me deixar ali na casa dos outros sem continuar com minha educação, resolveu pedir ajuda de freiras Missionárias Capuchinhas (da Ordem Franciscana). Entre elas, conheci Irmã Josefa e Frei Benigno, que vieram a ser meus padrinhos de batismo, Irmã Crisanta, minha madrinha de crismado, Irmã Clória e Irmã Leopoldina, que foram responsáveis por acompanhar meus estudos em Benjamin Constant e em outros municípios. Nessas idas e vindas, de acordo com as normas das freiras, tive que mudar de diversas escolas e viver em diferentes municípios do Alto Solimões. Em certo momento, cheguei a pensar em ser freira, mas essa ideia não durou muito e como faltava um ano para finalizar meu Ensino Médio, resolvi viver sozinha. Enquanto finalizava os estudos em Manaus, tive experiência em alguns empregos privados e meu padrinho Benigno e alguns Irmãos Maristas da Igreja me acompanharam nessa fase.

Após o término do meu Ensino Médio, no auge da minha decisão de que curso fazer, recebi a noticia de que um surto de malária e hepatite havia causado várias mortes de parentes na região do Vale do Javari, e que meus pais haviam perdido meus dois irmãos. Fui imediatamente para Atalaia do Norte para poder dar apoio a eles. Chegando lá, encontrei meus pais muito abalados física e emocionalmente, precisando de assistência médica, e, para permanecer ali com eles, eu vi que necessitava de um espaço decente, que fosse meu, para cuidar da saúde deles. Resolvi então comprar uma casa na cidade para acolhê-los. Não voltei para a aldeia porque não tinha irmãos que pudessem me ajudar a viver na aldeia.

Mesmo ciente da luta difícil que iria enfrentar tanto na cidade como em meio ao movimento indígena por ser mulher, sabendo que me encontrava numa sociedade que privilegia o domínio político masculino, eu nunca me senti intimidada. Continuamente me incentivei a iniciar minha luta ali decretando para mim mesma que iria enfrentar as dificuldades de cabaça erguida. Sempre com incentivo dos meus pais, em alguns momentos consegui trabalhar no movimento indígena em alguns empregos temporários. Percebi que as "lideranças" que se encontram à frente do movimento indígena ainda não estão preparadas para 
incentivar ou acompanhar jovens que planejam estudare, para isso, ingressam no mundo ocidental. Mediante a ameaça que a influência não indígena apresenta para a coletividade de nossa sociedade, as lideranças escolhem a solução mais fácil para elas, que é empurrar o jovem de volta para aldeia. Apesar de, ou justamente por conta disso, os pais acabam perdendo um pouco de autoridade sobre seus filhos, fragilizando a importância de seu conhecimento tradicional, enquanto os filhos, por sua vez, imaginam que obter o conhecimento dos brancos significa ter que desprezar o conhecimento dos pais. Temendo cometer estes "erros", desde que eu comecei a estudar, meus pais tiveram a preocupação de me conscientizar e ensinar os valores da nossa cultura.

A responsabilidade que assumi de cuidar dos meus pais na cidade me fez deixar de lado o sonho de estudar numa universidade federal. Eu descartei a esperança de contar com apoio do movimento indígena em função da minha experiência anterior. Sozinha, não teria recursos para me manter em outra cidade, e assim pensei em me arriscar e realizar um sonho do meu pai fazendo um curso técnico de enfermagem. Os primeiros seis meses eram a parte teórica. Quando, no semestre seguinte, chegou a parte da prática, vi que não devia continuar no curso contra a minha vontade, já que aquilo não era o que eu queria, e acabei desistindo. Quando eu soube que a Coordenação das Organizações Indígenas da Amazônia Brasileira (Coiab) em Manaus estava selecionando estudantes indígenas do Brasil para fazer um curso de Cestão Ambiental, candidatei-me com apoio dos meus pais. Foi um período de intenso intercâmbio com colegas de outras etnias durante seis meses no ano de 2006, e aí pude ter a certeza de que o curso que eu escolheria teria que ser de algum modo ligada ao estudo da sociedade. Para não perder mais tempo, passei a ficar de olho nos vestibulares, e assim que finalizei o curso de Cestão Ambiental soube que o Conselho Indigenista Missionário (Cimi) estava oferecendo uma vaga para o Curso de Antropologia Aplicada para indígenas interessados. O edital dizia que o custo da inscrição e o valor das disciplinas a serem cobrados pela ONG seriam pagos pela organização indígena, que deveria enviar uma carta pedindo a inclusão do indígena no curso. Imediatamente mostrei o edital para o coordenador e pedi que ele fizesse a carta indicando meu interesse. Passei uma semana inteira implorando, até que, talvez por estar cansado de ver minha cara, ele atendeu meu pedido. Com a carta em mãos, pedi permissão dos meus pais e viajei para Manaus, onde ia fazer o curso. Apresentei a carta na sede do Cimi, mas mal sabia eu que a promessa contida na carta seria ignorada. Iniciei o curso, mas passaram-se dois meses e me comunicaram que a ONG que tinha me inscrito não iria pagar porque eu não era merecedora da confiança deles. Assim que soube disso, recorri à Funai para que ela pudesse pagar a primeira parcela do curso, mas a resposta da Funai foi que eles não ajudavam quem estuda em um curso privado. 
Não me restou alternativa a não ser vender meu bem mais importante: meu enfeite corporal completo composto de um conjunto de colares feitos artesanalmente e que tinham imenso valor pessoal. Consegui vendê-los em algumas lojas de artesanato no centro de Manaus, mas ainda assim não consegui o montante necessário para pagar o curso. Liguei para meus pais. Minha mãe disse que eu deveria esquecê-los pois, segundo a convenceram, eu teria inventado uma grande mentira com intuito de abandoná-los. Ela não deu tempo para que eu explicasse o que tinha acontecido e desligou telefone. Nessa época, eu vinha me sentindo cansada e tendo febre noturna todos os dias, mas nem percebi que estava doente. Dois dias depois de ter distribuído meu currículo à procura de emprego, recebi uma ligação para comparecer a uma entrevista naquele mesmo dia dentro de duas horas. Me ofereceram um emprego como secretária no consultório de um dentista, que aceitei sem pestanejar. Fiquei de retornar na segunda-feira no endereço indicado. Voltando para casa com essa novidade-seria um novo começo para minha vida -, quando passei em frente ao posto de saúde local, fui acometida com um acesso de tosse tão forte que expectorei sangue e acabei desmaiando.

Quando acordei, me vi numa sala de atendimento, e o médico responsável me disse que eu estava com tuberculose, doença da qual eu nunca tinha ouvido falar. A equipe do lugar me perguntou onde e com quem eu morava e, como falei que morava sozinha, me internaram por três meses sem dar notícia a ninguém. Ao término do tratamento, depois de passada a fase mais perigosa da doença o médico meu deu alta para que eu administrasse o resto da medicação em casa. Voltei para Atalaia do Norte disposta a prestar vestibular para uma vaga na Universidade Federal do Amazonas (UFAM). O ano era 2008, e, tanto no dia da inscrição no exame como nos dias de prova, eu ouvia vozes dizendo: "Ela é mulher, para que deixá-la estudar tanto?"; "Mulher não é igual aos homens"; "Não podemos contar com o retorno dela, se ela conhecer um homem vai ser o fim da linha"; "O pai dela acredita que ela vai ser algo no futuro"; frases acompanhadas de risos ao fundo. Minha convicção só aumentava: eu seria vitoriosa.

Quando chegou a notícia de que eu havia sido aprovada no curso, ainda houve quem chegasse para mim e dissesse coisas como: "Esse curso que você escolheu, pouca gente escolhe, porque só tem valor para as pessoas de fora"; "Fazer antropologia é perda de tempo"; "É um curso para quem não tem nada para fazer"; "É ainda pior no seu caso porque você é índia, como você vai estudar a si mesma?". Quando eu chegava em casa e contava para meus pais, com quem então eu tinha me entendido, eles diziam para eu não ligar, mas que estavam preocupados com outra coisa, já que meus primos Ihes diziam que eu já tinha estudado demais, que ninguém sabia o que eu queria e que eu queria ficar só estudando porque eu tinha medo de trabalhar. Por conta disso, durante toda 
a minha graduação em Antropologia, tive que compartilhar o que aprendia com meus pais para que eles acreditassem que o curso não era um modo de enganá-los. Tudo que eu aprendia eu passava para meus pais, narrando as aulas e apresentando os textos dos autores estudados para que pudessem acompanhar. Contudo, não era uma questão de mostrar se eu pessoalmente tinha ou não entendido as aulas, mas de mostrar, antes de tudo, que mulheres também podem aprender, já que, para algumas etnias, uma mulher estudando seria o mesmo que nada.

Alguns discursos de determinadas lideranças indígenas só são favoráveis às ações afirmativas para ingresso na universidade se elas forem decididas de modo coletivos, já que desejam poder escolher quais serão os poucos representantes que terão a "honra" de usufruir das cotas. Para esse pensamento, a ideia de um indígena poder se inscrever individualmente para uma cota na universidade seria apenas um modo de afastar jovens indígenas que estão interessados em ingressar no mundo acadêmico de suas coletividades. Pergunto-me, entretanto, por que não seria possível que as lideranças continuassem a acompanhar os percursos de quaisquer jovens indígenas na universidade, do mesmo modo como meus pais fizeram comigo? Quando há jovens que lutam para estudar no mundo dos brancos a qualquer custo e só recebem apoio dos brancos, a meu ver quem perde são os povos a quem esses jovens pertencem. Os estudantes indígenas precisam ser cobrados pelos dois mundos desde o início do Ensino Fundamental, no Ensino Médio e até o Ensino Superior. Apesar das calúnias que inventaram contra mim para que eu desistisse dos meus estudos, eu perseverei.

Eu senti a mudança de perspectiva dos meus parentes quando ingressei na universidade. É claro que ainda tenho um longo caminho a percorrer, e a prova disso é minha pesquisa sobre o artesanato marubo, a pedido das mulheres marubo e da minha querida mãe, que Kanavoã a tenha, que com muito orgulho chegou a presenciar o final do meu curso de Bacharelado em Antropologia na Universidade Federal do Amazonas feito de 2008 a 2014. Atualmente, estou cursando o doutorado no Programa de Pós-Graduação em Antropologia Social do Museu Nacional (UFR]), dando continuidade à pesquisa do artesanato marubo como cultura material e como cultura imaterial. Sou grata por ter vencido vários obstáculos, e minha luta não parou. Agora, queiram ou não, os homens estão precisando camuflar seus machismos, há muitas famílias começando a ter uma experiência parecida com a dos meus pais e os estudantes que vêm para a cidade estudar não precisam mais sentir o impacto que eu senti de viver como a única da espécie no mundo, de não ver ninguém semelhante falando a sua língua. Hoje em dia, mesmo estando nas metrópoles, encontro indígenas em qualquer esquina, enquanto na época que eu cheguei à cidade eu só me achava parecida comigo mesma. 
Nelly Duarte é optante indígena, Mestre e doutoranda no Programa de Pós-Graduação em Antropologia Social (Museu Nacional/UFR]).

\section{My life as Student in White World}

\section{ABSTRACT}

This text was written due to an invitation to talk about the affirmative action policy for admission to the Postgraduate Program in Social Anthropology of the National Museum of the Federal University of Rio de Janeiro. As a Marubo indigenous student, I recount in these pages how my admission into non-indigenous society took place. This reflection necessarily involves a presentation of my ethnicity and more specifically my family, the difficult path that led me to study and enter university and finally the ways I found to overcome obstacles most diverse. I conclude with an assessment of the importance of affirmative action in postgraduate education and the role of indigenous leaders in this process.

\section{KEYWORDS}

Affirmative action, Racism, Postgraduate education,

Amerindian peoples, Social anthropology.

Recebido em 30.10.2016. Aceito em 16.03.2017. 